\author{
Angeloantonio Russo (contact author) \\ Department of Management \\ LUM University \\ S.S. $100 \mathrm{~km} 18$ \\ 70010 Casamassima (BA), Italy \\ tel. +39.080 .6978111$ \\ fax. +39.080 .6977122$ \\ email: russo@lum.it
}

\author{
Clodia Vurro \\ Department of Economics, Management, and Quantitative Methods \\ University of Milan \\ via Conservatorio 7 \\ 20122 Milan (Italy) \\ tel.+39.02.503.21572 \\ email: clodia.vurro@unimi.it
}

\author{
Rajiv Nag \\ Department of Management \\ LeBow College of Business \\ Drexel University \\ Philadelphia, USA \\ Email: Rajiv.Nag@drexel.edu
}




\title{
TO HAVE OR TO BE? THE INTERPLAY OF KNOWLEDGE STRUCTURE AND MARKET IDENTITY ON KNOWLEDGE-BASED ALLIANCE FORMATION
}

\begin{abstract}
We explore how a firm's knowledge structure characteristics and market identity - as reflected in its position in the industry value chain and market status - influence knowledge-based alliance (KBA, hereafter) formation. We propose that the firm's propensity to form KBAs is affected by congruence (or misalignment) between its knowledge structure characteristics (namely, knowledge depth and scope) and the role it plays in the industry as demanded by its position in the value chain. We also argue that while a firm's market status can amplify the positive effect of congruence, thereby enhancing a firm's proclivity to form KBAs, being prominent can also hurt a firm when it faces a misalignment between its knowledge structure characteristics and externally induced expectations related to its value chain position. We validate our arguments using panel data on 1,051 firm-year observations on the tendency to form KBAs over the period 1999-2009 by 197 firms patenting in the global fuel cell industry. By developing a richer understanding of the relationship between a firm's knowledge-based resources and KBA formation, we answer the call for a better understanding of how and when firms can leverage on internal knowledge configuration to improve their proclivity to form alliances.
\end{abstract}

Keywords: Alliance Formation; Knowledge-based Alliances; Knowledge Structure; Market Identity; Emerging Industries

JEL code: M10, O32, O33 


\section{INTRODUCTION}

Over the last two decades, knowledge-based alliances (KBAs, hereafter) have substantially grown in popularity (Berchicci, 2013; Kavusan et al., 2016). Widely defined as mutually beneficial agreements between independent organizations to purposefully either transfer or absorb the knowledge of the partner to explore novel domains (Anand and Khanna, 2000) or to maximize the joint utilization of complementary assets (Lavie et al., 2011), KBAs have attracted much scholarly and managerial attention as key tools to undertake technological development activities (Franco and Haase, 2015).

KBAs have been acknowledged as particularly critical in highly dynamic, emerging industries where few firms possess all the internal capabilities to cope with uncertainty related to steep rates of technology development (Rosenkopf and Nerkar, 2001; Subramanian et al., 2018). In an attempt to explain variety in firms' reliance on inter-firm collaborations, research has focused on the conducive role of internal knowledge base for predicting KBA formation (Zhang and BadenFuller, 2010). Yet, these studies have not fully accounted for those situations in which high uncertainty associated to unpredictable technological dynamics tempers KBA attractiveness. Particularly in emerging industries, firms often find themselves engaged in struggles for legitimacy and recognition, that can pose challenges for them in attracting alliance partners (Colombo et al., 2006). In these contexts, it is likely that firms draw on attributes that are thought to be causally related to the potential partners' ability to successfully fill expected tasks. Recent research identifies market identity as one uncovered attribute affecting alliance-based decisions (Jensen et al., 2011b). Indeed, market identity specifies the roles and expectations that market actors ascribe to the firm to represent the external demands surrounding a firm's alliance decisions (Porac et al., 1989). 
The analysis of knowledge-based determinants and identity-based drivers of KBA formation have tended to largely follow independent paths (Meier, 2011), leaving the question of how and why certain contextual factors affect KBA formation mostly unanswered (Franco and Haase, 2015; Meier, 2011).

Heeding the call for a better understanding of the conditions affecting firms' ability to complement internal knowledge generation with external knowledge brokering in dynamic technological environments (Lavie et al., 2011; Stern et al., 2014), we develop and test a framework showing the moderating effect of market identity on firm's ability to leverage on its internal knowledge structure to form KBAs in emerging, dynamic industries. According to recent literature on relational pluralism (Shipilov et al., 2014), we develop a construct of market identity along two dimensions, that is, value chain position occupied by a firm in the industry and its relative market status derived from embeddedness into that industry structure. We assume that, while the firm's knowledge structure characteristics influence its internally generated logics towards KBAs, market identity acts as a legitimating resource tied to larger sociocultural norms that may enhance or abate a firm's ability to form KBAs in emerging contexts.

We locate our study in the global fuel cell industry, by tracking alliance behavior, knowledge structure, and identity of firms over the period 1999-2009. The worldwide fuel cell industry is still characterized by uncertainty regarding the dominant technological design and product applications (Schoots et al., 2010; Wei et al., 2017). These peculiarities lead firms to rely on legitimating signals to hedge against the risk intrinsic in technological portfolio composition through intra- and inter-firm strategies (Vasudeva and Anand, 2011). Thus, this context provides a robust setting to dig deep into the moderating role of external demands for conformity on KBA behavior. 
Results support the importance of congruence between internal knowledge structure characteristics and external expectations related to having a certain market identity. In fact, we find patterns of variation between an amplifying and attenuating nature of KBAs depending on whether the firm occupies an upstream or downstream position in the industry value chain. We also find that while a firm's high market status can amplify the positive effect of congruence, thereby enhancing a firm's proclivity to form KBAs, the opposite is true when misalignment prevails between knowledge structure characteristics and externally induced expectations related to its value chain position.

These findings contribute to several research areas. First, we develop a richer understanding of the drivers of KBA formation, by bridging the internal (resource-based) and external (social- and market-based) perspectives on its drivers (Franco and Haase, 2015; Stern et al., 2014). Second, we enrich recent discussion on the importance of developing more market-oriented conceptions of an organization's identity (Baron, 2004; Livengood and Reger, 2010), by showing how occupying a certain position in the value chain may provide strong signal hindering investments in misaligned internal knowledge structures. Finally, we answer the call for further studies on firm's behavior in emerging contexts (York and Lenox, 2014), by offering fresh insights on KBA formation, when both resource endowments and alignment with external demands for conformity are critically interwoven in affecting strategic outcomes (Forbes and Kirsch, 2011; Subramanian et al., 2018; Zhang et al., 2007).

\section{THEORETICAL BACKGROUND AND HYPOTHESES}

\subsection{How knowledge depth and scope affect KBA formation}

In an attempt to explain the motivations and abilities of a firm to ally in the context of emerging technological fields, research has focused on the dimensions of a firm's knowledge base as 
determinants of its propensity to form KBAs (Subramanian et al., 2018; Zhang and Baden-Fuller, 2010). Accordingly, knowledge depth and scope have emerged as two distinct dimensions of a knowledge base that predict alliance behaviour by revealing both the structure and the content of the knowledge a firm holds (Katila and Ahuja, 2002; Wang and von Tunzelmann, 2000; Wang and Rajagopalan, 2015).

Derived from the repetitive use and development in a few specialized knowledge domains, knowledge depth is defined as the level of sophistication and complexity of knowledge in key fields (Schilling and Green, 2011). The nature of learning underlying a depth orientation can be considered to be exploitative (March, 1991) and results in refinement, implementation, efficiency, and production (Ahuja and Katila, 2001). Knowledge depth is conducive to KBA formation. Ahuja (2000), for instance, found that the possession of highly specialized technological knowledge makes a firm attractive as a potential alliance partner. Additionally, firms with a deep understanding of the dynamics occurring within their industry are better at evaluating and assimilating external knowledge, having developed internal heuristics and routines to scan and recognize external opportunities (Berchicci, 2013). Finally, whereas knowledge depth can generate clearer, earlier, and closer efficiency returns, rapid learners may experience progressive reduction in resources allocated to exploration of new domains, thus suffering from the limits of inertial behaviour (Tripsas and Gavetti, 2000). Accordingly, recent research has agreed on the need to complement internal specialization with external knowledge generation, thus relying on KBAs to counter the sources of myopia induced by exploitation (Hagedoorn and Wang, 2012; Schmiedeberg, 2008).

Reliance on external partners to explore new knowledge is expected to be even more critical in emerging industries where internal specialization, that is, knowledge depth, can lead to competence trap in sub-optimal learning trajectories before a dominant design emerges (Mata and 
Woerter, 2013). KBAs are more attractive for firms as technological uncertainty and dynamism grow, to adjust the technologies developed in-house with those developed by other firms. In this way, they can also overcome conflicting domain-specific pressures imposed by organizational inertia and absorptive capacity (Leiponen, 2005). Moreover, if the firm is uncertain as to the future knowledge requirements of the domain in which it has already accumulated knowledge, KBAs offer an opportunity to spread risks. Finally, a greater depth orientation allows firms to develop a rich and higher-order understanding of the knowledge domains in which they specialize, thus improving their attractiveness as superior allies to others hoping to acquire greater knowledge through that partnership (Zhang and Baden-Fuller, 2010).

Therefore, we posit that:

Hypothesis 1: The more depth-oriented knowledge structure that a firm has, the greater will be its tendency to form KBAs.

Knowledge scope, or the extent to which a firm's knowledge base spans across a variety of knowledge domains, also facilitates firms in dealing with interorganizational relationships (Zhang and Baden-Fuller, 2010). Knowledge scope provides firms with a broader repertoire of heuristics to evaluate the quality of untested technological capabilities in newly emerged technological domains (Colombo et al., 2006), resulting in higher propensity to form KBAs (Hagedoorn and Wang, 2012; Zhang et al., 2007). Empirical evidence abounds on how a diverse knowledge base impacts on firms' ability to extract value from technological developments headed by prospective partners (Arora and Gambardella, 1990), as well as develop superior coordinating routines and combinative capabilities that enable them to harness divergent knowledge streams within their boundaries (Grant and Baden-Fuller, 2004; Kavusan et al., 2016). As a consequence, knowledge scope turns into superior ability to predict and identify combinatorial opportunities that are novel and path-breaking, thereby enhancing the potential 
benefits that firms can realize from KBAs (Rosenkopf and Almeida, 2003; Rosenkopf and Nerkar, 2001). Therefore, we posit that:

Hypothesis 2: The more scope-oriented knowledge structure that a firm has, the greater will be its tendency to form KBAs.

The pursuit of both specialization into knowledge domains and exploration of a diverse set of knowledge trajectories is not costless and straightforward. Depth and scope reflect different organizational structures (Zhou and Li, 2012), different mind-sets due to contrasting time horizons (March, 1991), and different organizational routines and incentive schemes (Hoang and Rothaermel, 2010). Such underlying incompatibility between the two learning strategies has fostered an intense debate over how to configure the most appropriate knowledge base to support KBA formation (Meier, 2011). Such decisions become even more critical in emerging industries, where investing in both depth and scope can be constrained by higher risks and uncertainty (Forbes and Kirsch, 2011). Moreover, in the emergent face of a new technological domain firms find it more complex to recognize the potential value of partners' knowledge that may unfold as technology develops, thus making knowledge base an insufficient driver of KBA formation (Clegg et al., 2007).

\subsection{The moderating role of market identity}

The arguments above suggest that emerging industries add a layer of complexity in KBA formation. Faced with high uncertainty and limited or incomplete information in assessing the value of inter-firm collaborations, firms may need to leverage on more observable characteristics to attract, and be attracted by, potential partners (Hoenig and Henkel, 2015). Therefore, there is a need to consider social and market factors in the broader industry context which, when interacting with a firm's knowledge structure, may offer a richer and fuller understanding of how and when internal knowledge characteristics affect KBA formation patterns. 
Defined as the firm's role and expectations, as consensually held by other social actors in the market (Jensen, 2010; Navis and Glynn, 2010), market identity has been recently included among the key drivers leading to alliance formation (Chung et al., 2000; Jensen et al., 2011a; Kogut and Zander, 1996). Market identities embody socially constructed properties that a firm can legitimately possess given the role it occupies in the market space. Identities are generally used as signals of resources and competences, thus representing a key factor in affecting strategic and competitive behaviour of firms (Hsu and Hannan, 2005; Livengood and Reger, 2010). In particular, research shows that when firms deviate from their ascribed market identity or when there is a perceived gap between a firm's market identity and its internal characteristics, they tend to suffer in terms of legitimacy and performance (Benner, 2007; Zuckerman, 1999). Market identity plays an important role in reducing information asymmetries and buffering the risk of mistaken evaluations in the early stages of alliance formation (Glynn and Navis, 2013; Uzuegbunam, 2016). This becomes vital in emerging industries where technologies are still in their infancy, requiring further developments to reach the market, as well we the market itself could not exist yet. Uncertainty, non-codifiability, and opacity may represent common features of immature technological environments making it complex for firms to simply rely on their knowledge base to attract potential allies. Indeed, potential partners are likely to rely on cognitive, socially constructed shortcuts as signals of partnering quality and appropriateness (Jensen et al., 2015).

Prior studies on relational pluralism and social categorization have recently bridged two major perspectives on market identity and its impact on firm-level outcomes (Shipilov et al., 2014). First, marked identity provides a classification of a firm as a member of a particular category, which codifies commonly held beliefs and expectations about what constitutes legitimate actions (Hsu and Hannan, 2005; Tripsas, 2009). Accordingly, market identities can be related to the 
product or geographic markets firms are affiliated with, as well as positions in their industry along the value chain. Value chain positions are crucial in the context of inter-firm collaborations, as they represent signals to the partners regarding what constitutes acceptable proposals (Kim and Jensen, 2011). Second, market identity also originates from the structure of the social system a firm belongs to (Podolny, 2001). While social categories resemble roles and expectations, having a more or less prominent social role within a given social structure of relations allows peers to make inferences about the status of a potential ally (Podolny, 2010). Thus, market status defined as the firm's position in a hierarchical order, tied to the pattern of affiliations and relations in which it is embedded, shapes others' expectations about each firm's influence in that context (Blau, 1977; Graffin et al., 2013). Whereas the position of the firm along the value chain delineates what it is expected to do, this second dimension - market status signifies the perceptions of external actors about how prominent the firm is while performing its ascribed roles. In emerging-stage industries, the second dimension becomes particularly relevant as firms are often engaged in strong competition to gain legitimacy for their market positions and activities (Glynn and Navis, 2013). Therefore, it is likely that the ordering of market identities in these industries will emphasize not merely the division of roles, but also the status of incumbents in those roles.

How market identity, along its two dimensions, interacts with internal knowledge structure to affect a firm's proclivity to form KBAs still needs further investigation. 


\section{nfluence in \\ interfirm rela- \\ tionships}

\subsubsection{The interplay of knowledge structure and value chain position}

Market identity is articulated into a set of categories representing the assignment of different roles to actors along a value chain, ranging from upstream raw-material suppliers, research labs, and universities, to downstream end-users and commercial developers (Jensen et al., 2011b). Upstream and downstream firms are likely to have highly divergent modes of value creation, knowledge bases, and managerial processes (Isaksson et al., 2016; Stuart et al., 2007). Scholars have observed that customer and market diversity increase from upstream to downstream positions. Upstream firms tend to specialize in narrow, modular technologies that are then combined by downstream firms to meet the needs of a wider variety of consumer markets (Gambardella and McGahan, 2010).

Scholars have extensively observed that in emergent-stage technology industries, firms engage in KBAs with upstream firms to get access to high quality scientific and technological knowledge (Hagedoorn and Wang, 2012; Jensen et al., 2015; Silverman and Baum, 2002). Thus, external audiences expect upstream firms to have strong technological expertise in few selected knowledge domains. As a consequence, firms occupying upstream positions along the value 
chain will enjoy greater proclivity to KBAs when they have depth-oriented internal knowledge structures.

On the other hand, developing depth-oriented knowledge structures can pose contradictory demands for downstream firms that are expected to be more engaged in end-user markets that require the combination of multiple technological, manufacturing, and commercial knowledge trajectories (Hagedoorn and Wang, 2012; Hess and Rothaermel, 2011). Downstream firms with a depth-oriented knowledge structure can face critical trade-offs between focusing on developing in-depth understandings in a few chosen knowledge domains and technologies or spanning and combining a wide array of customer segments and needs, and technological attributes. External audiences could read this approach as a signal that the firm is not clear in its intentions and could devalue its potential contributions as an alliance partner. Therefore, we propose that:

Hypothesis 3: Holding a depth-oriented knowledge structure has a different impact on the tendency to form KBAs for firms at various stages along the value chain. Specifically, downstream firms with an increasingly depth-oriented knowledge structure will form fewer KBAs relative to firms in upstream positions.

When we consider the scope of a firm's knowledge structure, an opposing logic is likely to apply. Upstream firms with scope-oriented knowledge structures are likely to face misalignment challenges. The routines and organizational processes underlying a scope-oriented knowledge structure are likely to be perceived of limited use for upstream firms that are expected to offer deeply specialized technological knowledge (Gambardella and McGahan, 2010; Quintana-García and Benavides-Velasco, 2008; Rothaermel and Deeds, 2004).

On the other hand, downstream firms experience demand heterogeneity because they interact with a greater variety of needs relative to upstream firms. Consequently, when downstream firms 
develop greater levels of internal knowledge scope, they are likely to provide reassuring signals to external audiences about their intentions and abilities. Hence:

Hypothesis 4: Holding a scope-oriented knowledge structure has a different impact on the tendency to form KBAs for firms at various stages along the value chain. Specifically, downstream firms with an increasingly scope-oriented knowledge structure will form more KBAs relative to firms in upstream positions.

\subsubsection{The interplay of knowledge structure and market status}

Although our arguments so far have focused on the likely effects of alignment (or lack thereof) between a firm's knowledge base characteristics and its value chain position, we posit that this relationship needs to account for a firm's status, that is, how prominent a firm is in performing its expected roles in the eyes of market actors. Prior research has shown status of the involved partners to be an important driver of alliance formation (Chung et al., 2000; Stuart, 1998). Status however, can be a double-edged sword (Chen et al., 2012). Some studies have provided insightful evidence that high status social actors can end up facing greater scrutiny and attracting stronger punitive responses when they are seen as deviating from expected norms of behavior, unless they are able to send reassuring signals about their market identity (Jensen, 2010). We argue that upstream firms will display greater alignment relative to downstream firms when they possess greater depth-oriented knowledge structures. Having greater market status will help strengthen the positive attributions of alignment when a firm occupies an upstream position. Conversely, in the case of a misalignment, having high market status can exacerbate negative attributions that the firm might face from external actors. Therefore, we argue that:

Hypothesis 5: There is a three-way interaction between knowledge depth, value chain position, and market status in influencing a firm's ability to form KBAs. Specifically: 
Hypothesis 5a: When firms in upstream value chain positions pursue increasingly depthoriented knowledge structures, higher market status will strengthen their ability to form KBAs.

Hypothesis 5b: When firms in downstream value chain positions pursue increasingly depth-oriented knowledge structures, higher market status will weaken their ability to form KBAs.

When we consider the scope dimension of a firm's knowledge base, a converse picture emerges. As argued earlier, scope orientation aligns well with the external role of downstream firms as they have to straddle diverse customer needs and market opportunities. Market status will further strengthen this alignment for downstream firms. On the other hand, upstream firms will suffer from a perceived misalignment when they have increasingly scope-oriented knowledge base configurations. Furthermore, market status will heighten the deleterious effects of this misalignment in the eyes of external market actors. Hence:

Hypothesis 6: There is a three-way interaction between knowledge scope, value chain position, and market status, in influencing a firm's tendency to form KBAs. Specifically: Hypothesis 6a: When firms in upstream value chain positions pursue increasingly scopeoriented knowledge structures, higher market status will weaken their ability to form KBAs.

Hypothesis 6b: When firms in downstream value chain positions pursue increasingly scope-oriented knowledge structures, higher market status will strengthen their ability to form KBAs.

Figure 1 shows a visual description of the aforementioned hypothesized relationships. In the following sections, we present the design and results of our empirical study. 
Insert Figure 1 about here

\section{METHOD}

\subsection{Empirical setting and sample}

A key issue in the empirical design of our study was the selection of an appropriate research setting. We needed an empirical context able to simultaneously satisfy the following requirements: first, dynamisms and uncertainty as typical of emerging industries or technological domains where clarity is still to come regarding what to exchange with, and what to expect from potential allies; second, relevance of knowledge as a key asset to be developed internally and exchanged externally through KBAs; third, heterogeneous identities suggesting heterogeneity in capabilities.

We selected the global fuel-cell industry for the empirical analysis because it satisfies the criteria above. Heeding the call for effective technological solutions to global warming and energy security in a context of increasing energy demand, fuel-cell industry has attracted worldwide attention as a truly non-polluting source of electricity. Fuel cells are devices that electrochemically combine fuels (e.g., methane, methanol, natural gas, gasoline, hydrogen) and oxygen to produce electricity and water. Water evaporation is the only emission in the energy conversion process. Thus, when combined with hydrogen a fuel cell system becomes a zeroemission source of electricity, making energy production environmentally sustainable. Dated back to the mid- $19^{\text {th }}$ century, it is only during the Nineties that these technologies have achieved radical improvements and substantial reduction of cost per unit, greater number of potential applications (e.g., portable electronics, stationary electricity generators, and passenger vehicles), and supporting government policies to promote clean transportation and energy generation (Pilkington, 2004). Boosted by a generalized optimism for more imminent 
commercial possibilities, many fuel cell companies listed on stock exchanges in the late 1990s, with an unprecedented upraise in the number of patent applications and inter-firm collaboration agreements. Aimed at reaching competitiveness in performance compared to conventional technologies, fundamental research has dominated the scene till late 2000s, where the global economic recession marked a fundamental shift in the logics driving firms' engagement in the industry. Limited credit availability and restrictions in government funding, as well as lack of profitability for many organizations, have caused a number of firms to go out of business. Since then, commercial orientation has taken the lead over knowledge orientation (Avadikyan et al., 2012).

Given the arguments above, the decade 1999-2009 represented an ideal context for data collection and analysis. First, industry reports, previous analyses of industry trends, expert views and our own data collection converge on identifying that period as the most dynamic phase in the industry evolution (Brown et al., 2007; Wei et al., 2017). Turbulence, market uncertainty, high risks of failure and heavy cost structures have leaded to conflicting pressures on firms to accommodate the need for exploration of emerging technological patterns and exploitation of existing technologies to outperform rivals in the race to market commercialization (Vasudeva and Anand, 2011). Additionally, fuel cell technologies are driven by advancements spanning across a diverse set of scientific fields such as, for example, nanotechnology chemistry, and semiconductors. Despite this feature, fuel cells are highly generic technologies with application possibilities in a broad range of sectors and markets. As a result, the industry is still crowded with heterogeneous players belonging to different industries, with likely mismatches between how they appear on the market and the kind of technologies they develop internally. Finally, resource constraints and limited commercialization have pressured firms to form alliances with a prominent knowledge generation and acquisition objective (Avadikyan et al., 2012). 
In that our research design aimed to investigate the interplay between knowledge structure and market identity to predict alliance formation, we tested our hypotheses on a longitudinal dataset combining patenting activities and KBAs in the global fuel cell industry over the period 19992009. The use of time-varying data on the same set of firms is particularly appropriate to control for unobserved sources of firms' differences in terms of internal and external knowledgegeneration patterns (Yang and Steensma, 2014).

The data collection started with the identification of firms engaged in internal fuel cell-related knowledge generation, based on their patenting activities. Patents and patent citations are widely and consistently used as proxy for knowledge structure and flows (Hagedoorn and Cloodt, 2003; Katila and Ahuja, 2002). We relied on the United States Patent and Trade Office (USPTO), the European (EPO) and Japanese Patent Offices (JPO) to gather patent data. More specifically, we content analysed patent documents to identify relevant patent applications ${ }^{1}$. Patents were aggregated at consolidated level, that is, comprising both patents applied by the parent firms and all the consolidated subsidiaries. This stage of the analysis generated a total of 560 firms that had engaged in patenting activity in the fuel cell industry during the timeframe of our study.

In the second stage of the data collection process, we searched for KBAs formed by the 560 patenting firms identified above. We collected alliance data for each firm by searching archives of news reports, industry journals and trade magazines compiled in the Dow Jones and Factiva databases. We also consulted corporate websites and news articles in the Lexis-Nexis database to cross-validate the alliance announcements. Within the whole set of alliances identified, we

\footnotetext{
${ }^{1}$ We used both technology areas (e.g., fuel cell solid electrolytes, electrodes, catalysts, membranes, systems) and fuel cell-related International Patent Classification (IPC). In this regard, we tracked fuel cell patent applications using all the subsets of the two fuel cell-related IPCs, i.e., H01M008 (fuel cell classification) and H01M004 (electrodes classification).
} 
selected those in which a combined innovative activity or an exchange of knowledge or technology was engaged between partners, that is, R\&D alliances (Hagedoorn and Wang, 2012). Finally, we considered the firm-year the unit of analysis, as our dependent variable captured firmlevel tendencies, that is, proclivity to form KBAs. Accordingly, we matched patent data with agreement data, by pooling them across all KBAs formed by each firm in a given year. Our final sample is an unbalanced longitudinal dataset comprising 1,051 firm-year observations consisting of KBAs between 197 unique alliance partners.

\subsection{Variables and measures}

\subsubsection{Dependent variable: KBAs}

As we were interested in investigating the tendency to engage in KBAs, we operationalized our dependent variable as the number of new $\mathrm{R} \& \mathrm{D}$ alliances completed by each firm $i$ in the sample at time $t$ (Gulati, 1999; Stuart, 1998; Zhang et al., 2007). To be included in the alliance count, agreements had to be based on exchange or development of fuel cell technologies. All those agreements having distribution, supply, and marketing contents were excluded from the analysis. According to previous studies identifying $R \& D$ alliances as the most knowledge-generating interorganizational agreements, we ended up with a sample of development agreements, R\&D contract, R\&D joint ventures and research corporations (Lavie and Rosenkopf, 2006). As illustrated by the excerpts below, an alliance was classified as R\&D if it suggested a potential for knowledge flows between partners, and/or if it explicitly stated that the agreement surrounded a joint $R \& D$ interest.

H Power and Synergy Technologies announced the signing of a development agreement to pursue development of fuel cell systems utilizing H Power's proton exchange membrane (PEM) fuel cell technology and Synergy's patented SynGen cold plasma process for reforming heavy fossil fuels to produce hydrogen (FyelCells.org, April 18, 2002)

Medis Technologies Ltd., creator of the world's first consumer portable fuel cell, together with Vitrociset, a leading Italian defense company, announced today that the two companies have entered into an exclusive agreement for the development and adaptation of Medis' fuel cell technology for battery use in tactical man 
pack radios, future soldier combat jackets and unmanned airborne vehicles (UAVs) for the Italian military market. Medis will work closely with Vitrociset to develop the first of its kind military specific portable fuel cell powered solution (RenewableEnergyFocus.com, April 8, 2009)

We lagged our independent variables and controls by two years relative to the dependent variable to facilitate causal interpretation of our findings, as well as to control for potential endogeneity effects.

\subsubsection{Independent variables: Knowledge-based structure}

Though acknowledging the complexity of providing accurate measures of knowledge profiles, we relied on patents as widely employed by the academic community for classifying knowledgebased characteristics, that is, its depth and scope (Katila and Ahuja, 2002; Zhang et al., 2007). Patents gave us the possibility to classify their content into technological classes and capture firm-level tendency to either specialization into specific areas (knowledge depth) or exploration across multiple areas (knowledge scope).

A depth-oriented knowledge structure is one where the firm has accumulated experience within the same knowledge elements, under the assumption that the more often a certain knowledge is used, the more the experience in using it (Benner and Tushman, 2003). Accordingly, knowledge depth was measured as the number of times on average a given technological class in year $t$ was repeatedly referred to by the firm's $i$ patents during the prior five-year period. Therefore, knowledge depth was computed using the following formula:

$$
\text { Knowledge dept }_{i t-2}=\frac{\sum_{y=t-6}^{-2} \quad \text { repetition } \text { count }_{i y}}{\text { total technology } \text { classes }_{i t-2}}
$$

This formula captures the portion of total citations in year $t-2$ for firm $i$ that has been used in the previous five years. This is to say that for KBAs in 1999, we measured knowledge depth over the time period between 1993 and 1997. Similarly, we measured the scope of a firm knowledge base as its propensity to span across technological domains, that is, the proportion of previously unused technological classes in a firm's focal year's list of technology classes. We assessed the 
share of technology classes in a focal year as technology classes that were absent in the previous five-year list of patents filed by that firm. Therefore, knowledge scope is a variable that ranges from 0 to 1 ; it was computed using the following formula:

$$
\text { Knowledge scope }_{i t-2}=\frac{\text { new technology } \text { classe }_{i t-2}}{\text { total technology } \text { classes }_{i t-2}}
$$

In both cases, we used a five-year time window for patenting in order to control for annual fluctuations and get more accurate predictions of KBA formation rates. According to previous literature, it is reasonable to assume that alliance decisions are based on stocks of knowledge accumulated over time (Rothaermel and Deeds, 2004; Zhang et al., 2007).

\subsubsection{Moderating variables: market identity as value chain position}

To develop the first dimension of a firm's market identity, i.e., value chain position, we started from the analysis of the fuel cell value chain. Based on field expert consultation, industry reviews, and extant research, we were able to identify roles companies are expected to play moving from component and material suppliers on the upstream, to system integrators and end users on the downstream end (Avadikyan et al., 2012; Nygaard, 2008).

At the materials level, firms engage in technology development projects related to catalyst material, gas diffusion layers and electrodes, and membrane electrode assemblies. Firms in this position play a crucial role in fundamental technology development aimed at improving the functionality of the various components that are crucial for improving the performance of the whole system. These firms are expected to be highly specialized in one particular component or sub-system, insisting on a given knowledge domain (e.g., chemistry or materials). At the same time, in order to connect with system integrators as tier-1 suppliers, they have to develop competences across all application areas, spanning from the automotive value chain to stationary applications. The basic materials, components and sub-parts are then assembled by firms usually 
called system integrators, which then produce the complete fuel cell. At the system integration level, firms have a key role in connecting the different component and material developers, integrating their technologies into a fuel cell system and establish links to end-user firms in the different potential markets (e.g., stationary or transport markets). It is vital for system integrators to nurture a diversified knowledge portfolio to be able to recognize upstream technological developments. At the same time, specialization in application markets supports them in getting faster access to distributors and end users. Further down the value chain are distributors and industrial end-users such as automotive companies and power utilities that apply fuel-cells in their final products and services. End users are key for market development in specific application markets. Yet, because of uncertainty concerning the technological design or products that will achieve commercialization, they have to hedge against the risk of over-commitment to limited technology portfolios (Vasudeva and Anand, 2011).

In sum, the division of roles in the industry leads to associate narrow, specialized technological competences to upstream actors, whereas those that are further downstream are perceived as pursuing more diverse activities on account of the wider range of actors and market conditions that they engage with. Moving from roles to knowledge-structure, the balancing between depth and scope orientation in building the knowledge base is pervasive throughout the value chain, such that upstream firms could also have a scope oriented knowledge structure, as well as downstream firms could invest into more specialized knowledge bases (Hagedoorn and Wang, 2012).

We identified each firm's value chain position by consulting secondary published material about the firm such as annual reports, industry study reports, industry trade association websites, and articles in the trade and industry journals. Using these sources, we generated a detailed profile for each firm in our sample. Patterns in the data led us to reduce the fuel cell value chain into five 
categories moving from upstream to downstream: component and material suppliers, technology and research providers, manufacturers and integrators, distributors, and end users. We then developed a five-point scale variable ranging from -2 for upstream actors to +2 for actors occupying downstream positions along the fuel cell value chain (Uzuegbunam, 2016).

\subsubsection{Moderating variables: market identity as market status}

According to previous research, we measured market status as degree centrality within the network of pre-existing strategic alliances (Jensen, 2003; Lin et al., 2009; Podolny, 1993). Centrality refers to each actor's position relative to other in the network, with greater centrality corresponding to a more prominent intermediary position (Gulati, 1999). Accordingly, centrality reflects the extent of a firm's relative status, given by the structure of the relationships in which it is embedded (Lin et al., 2009). To compute network centrality scores for the firms in our sample, we constructed the industry network for each year, considering the alliance activity of the sample firms in the previous year. We used this time-window based on the fast pace of change, characterizing the industry. We constructed adjacency matrices for each year to compute the centrality scores, where the matrices represent the relationship between the 197 firms in the previous year. We measured centrality locally (i.e., degree centrality), as the number of other firms connected to each focal firm, ignoring how well those partners are connected. Degree centrality is a common measure of the centralization of power within a network (Powell et al., 1996), such that the greater the firm centrality with the formal collaboration network becomes, the greater the central actors' access to others within the network and the greater that actor's power to provide or withhold access to others within the network. We computed the centrality scores using UCINET 5.

\subsubsection{Controls}


We introduced several controls in the study that might influence firm alliance behaviour according to previous research. First of all, larger firms are more likely to enter into alliance than smaller firms. There are many reasons why this may happen. Large firms have usually slack resources to be invested into collaborative agreements (Dickson and Weaver, 1997). Further, they may suffer from inertial behaviour given the need for routinization and formalization, thus making reliance on KBAs more than needed (Rothaermel and Deeds, 2004). We therefore, controlled for firm size, measured as the log of the number of employees of the firm. Similarly, we controlled for financial solvency ratio as firm's long-term debt-equity ratio. We also accounted for a firm's intangible assets as representative of its absorptive capacity to manage external knowledge flows more efficiently (Subramanian et al., 2018). Consistent with prior research, we developed a log-transformed composite measure of a firm's R\&D and Advertising Intensity (Gambardella and McGahan, 2010). We collected key financial data from a number of sources, including the Orbis database and annual financial reports. As our sample included both private and listed companies, we included a dummy variable, coded 1 for public companies, 0 otherwise. In this way we ruled out potential heterogeneity due to higher visibility and attractiveness of listed companies compared to private ones. We also accounted for potential path dependence in alliance formation decisions, by controlling for prior partnering experience (Anand and Khanna, 2000). In order to measure partnering experience we counted all prior fuel cell alliances formed by a focal firm with any partner between 1999 and the preceding year (Lavie and Rosenkopf, 2006). We then divided the total number of prior fuel cell alliances by the total number of prior alliances signed by any firm in the sample. Thus, we obtained a partnering experience ratio corresponding to firm-level experience compared to all the others in the sample. Similarly, to account for potential inertial forces based on experience (Kelly and Amburgey, 1991), we included firm age as a control for the analysis, measured as the difference between the 
focal year and the year in which the firm applied for the first fuel cell-related patent. We also included a measure of firm engagement in acquisitions in a given year, acquisition experience, to account for alternative modes for undertaking exploration outside the firm's boundaries (Lavie et al., 2011).

We accounted for specialization to capture the extent to which firms primarily focus on the fuel cell industry. This was necessary since several of our firms have operations outside the fuel cells industry (Zhang et al., 2007). We used the following formula to compute specialization:

$$
\begin{aligned}
& \text { FC Patents }{ }_{i t} / \sum_{i=1}^{n} \text { FC Patents } s_{i t} \\
& \text { Specialization }_{i t}=\frac{\text { Patents }_{i t} / \sum_{i=1}^{n} \text { Patents }_{i t}}{}
\end{aligned}
$$

where FC Patents it is the number of fuel cell patents by firm $i$ at time $t$, Patents it is the total number of patents by firm $i$ at time $t$, and $\mathrm{n}$ corresponds to the total number of firms included in the sample. Specialization varies around one, such that a value higher than one suggests that a firm is comparatively more specialized in the technology in question, given its overall innovative performance.

We controlled for industry effects using 2-digit US SIC codes (industry dummy variables) for eight industry categories and reduced them to four industries due to the distribution of firms in those categories, namely, plastics materials and synthetics, electrical industrial apparatus, R\&D and testing services, and other industries. We used the "other industries" group as the base value. We used a similar approach for controlling the country/regional effects considering the geographical location of each firm in the sample (country dummy variables). We created four country (regional) dummy variables viz. Asia, Europe, North America, and Other countries. We used the other countries group as the base value. Lastly, we accounted for temporal effects by including year dummy variables. 


\subsection{Estimation procedure}

As our study includes company-year observations from 1999 to 2009, we ran populationaveraged regression models and used generalized estimating equations (GEE) to control for firm heterogeneity. The GEE method is based on a general linear model and accounts for autocorrelation owing to repeated yearly measurements of the same firms by estimating the correlation structure of the error terms.

Our dependent variable, number of KBAs is a count variable taking on only non-negative integer values (i.e., the number or knowledge-based strategic alliances for a firm in a given year). We conducted tests for over-dispersion on the dependent variables and found that the data violated the assumption of mean and variance equality required for a Poisson specification (Hausman et al., 1984). Therefore, our use of negative binomial estimation provides a significantly better fit for the data than the more restrictive Poisson model. Given the structure of our dependent variable, the GEE methodology offers a better treatment for over-dispersion and serial correlation (Liang and Zeger, 1986), especially for limited-range dependent variable (Ballinger, 2004). We used the Cook-Weisberg and White test statistics to check for the homoscedasticity assumptions and found the presence of heteroscedasticity (Cook and Weisberg, 1983; White, 1980). To account for heteroscedasticity, we used a robust-cluster estimator of the standard errors in our regression models. The robust-cluster variance estimator provides correct standard errors in the presence of any pattern of heteroscedasticity. This estimator allowed us to relax the assumption of independence of errors in the regression.

We were mindful of the potential for endogeneity in firms' decisions to engage in KBAs, as the proclivity to enter into alliances could be driven by managers' expectations based on firm experience, performance and industry conditions (Lavie and Rosenkopf, 2006). In order to account for potential simultaneity bias, we paid significant attention to appropriate lags between 
our independent and dependent variables. Lagging suspected variables is the most common approach to deal with potential endogeneity given its ease of implementation (Wooldridge, 2001).

As an additional test, we also adopted an instrumental variable approach, performing a two-stage least square estimation procedure with the aim of predicting our main independent variables (i.e., knowledge depth and scope) as a function of firm's size, age, intangible assets, solvency, partnering experience and knowledge structure at time t-1 (Lavie et al., 2011). ${ }^{2}$ We entered the predicted values of knowledge depth and scope from the first-stage models as independent variables in the second stage models, where the number of KBAs served as dependent variables. We then ran our second-stage models based on cross-section time series regression with firm fixed effects. ${ }^{3}$ Results from this procedure showed that both the regression coefficients and significance levels did not significantly change compared to the negative binomial GEE estimation procedure. Therefore, we decided to only report the results from the panel data negative binomial regressions using population averaging to control for cross-sectional heterogeneity, as it allowed us to take the count nature of our dependent variable explicitly into consideration.

Finally, we checked for potential multicollinearity in our independent variables, in two ways.

First, we assessed the variance inflation factors (VIF) by running OLS regressions and found that none of the values exceeded the accepted maximum of 10 (Chatterjee and Price, 1991). Second, in running our models, we systematically deleted one independent variable at a time, checking to

\footnotetext{
${ }^{2}$ Consistent with the continuous structure of the first-stage dependent variables, we performed a maximum likelihood estimation while accounting for the panel structure of the data and correcting for autocorrelation using first-order autoregressive process. Further, we accounted for unobserved heterogeneity by including fixed-effects parameters and controlling for year dummies.

${ }^{3}$ We also tested our models using random effects specification. However, the fixed effects specification resulted in superior estimation based on Hausman test (1978).
} 
see if the deletion changed the sign or significance level of any key independent variables (Hillman et al., 2007). Both were not affected, supporting our conclusion that multicollinearity had little impact in our analyses. Finally, as hypotheses 3, 4, 5(a, b), and 6(a, b), included interaction terms, we standardized the key variables prior to forming interaction terms (Jaccard and Turrisi, 2003). We used a hierarchical regression approach to test our hypotheses.

\section{RESULTS}

Table 1 shows the descriptive statistics and correlations for our variables. Table 2 shows the results from the regression analysis. In the first model (model 1), we introduced the control variables and found that solvency ratio (debt/equity) negatively influences a firm's tendency to form knowledge-based alliances; on the other hand, specialization in the fuel cell industry, prior alliance experience, and prior acquisition experience are positively related to alliance formation. This suggests that firms with prior experience in both alliances and acquisitions seem to form more alliances.

Insert Table 1 and Table 2 about here

According to hypothesis 1 firms with high knowledge depth are likely to engage in a larger number of KBAs. The regression results, presented in model 2, show that increasing knowledge depth is associated with a greater engagement in KBAs (model 2: $B=0.31, \mathrm{p}<.001)$. Hypothesis 2 suggested a similar argument for knowledge scope. The results show that the more firms have a scope-orientation in their knowledge structure, the more KBAs they form (model 2: $B=0.26, \mathrm{p}$ $<.01)$. 
The next set of hypotheses ( 3 and 4 ) investigated the effects of the interaction between a firm's knowledge structure characteristics (depth and scope) and the first dimension of its market identity (i.e., the firm's value chain position ranging from upstream to downstream) on the tendency to engage in KBAs. Model 3 shows a significant negative $(B=-0.46, \mathrm{p}<.001)$ moderating effect of value chain position on the relationship between knowledge structure depth and the tendency to engage in KBAs. This suggests that when firms have a knowledge structure oriented towards depth and occupy value chain positions tending downstream, they form fewer KBAs relative to those that are upstream. Therefore hypothesis 3 received strong support. Hypothesis 4 suggested that when firms develop scope-oriented knowledge structures, the moderation of value chain position is likely to be of a reinforcing nature, thus forming a larger number of KBAs. Our results (Model 3, Table 2) provide support for this argument, revealing a positive interaction between knowledge scope and value chain position on the tendency to engage in KBAs (model 5: $B=0.14, \mathrm{p}<.01$ ).

Hypotheses 5 and 6 argued that a firm's market status, i.e. the second dimension of its market identity, will affect the interaction of a firm's value chain position and its knowledge structure characteristics. Model 4 in Table 2 shows a strongly significant positive $(B=0.23, \mathrm{p}<.001)$ three-way interaction effect of knowledge depth, value chain position, and market status. As a whole, this result suggests that higher market status tends to reverse the negative effects of misalignment between a firm possessing a downstream market identity and holding a narrow, depth-oriented internal knowledge structure. For hypothesis 6 , results show a significant positive (model 5: $B=0.58, \mathrm{p}<.01$ ) three-way interaction effect of knowledge scope, value chain position, and market status. This result suggests that the positive moderating effect of value chain position on the relationship between scope and the tendency to engage in KBAs is strongly strengthened by a firm's market status. 
We sought deeper insights into the nature of the interactions between the variables included in our models by plotting the hypothesized relationships, for one standard deviation above and below the mean market identity values in our sample (Figure 2).

Insert Figure 2 about here

As seen in the upper-left plot, the relationship between knowledge depth and tendency to form KBAs is amplified moving towards upstream positions along the value chain. The upper-right plot shows that the positive relationship between knowledge scope and KBAs is enhanced for firms occupying downstream value chain positions. On the contrary, when firms occupying upstream positions tend to have greater scope in their knowledge structure, they form fewer KBAs.

The lower-left plot in Figure 2 shows the three-way interactions between knowledge depth, market status and position along the value chain. Market status aids upstream firms having high knowledge-depth. The slope for upstream firms is positive especially for high market status firms, as knowledge structure tends towards greater depth. As knowledge depth increases, high market status downstream firms see an increase in KBAs formation compared to low market status counterparts. Yet, countering hypothesis $5 \mathrm{~b}$, prominence in a market space alleviates the negative impact of having a mismatch between a depth-oriented knowledge structure and value chain position.

The lower-right plot displays the three-way interaction between knowledge scope, market status, and value chain position on the tendency to form KBAs. A sanctioning effect dominates in the case of upstream firms. Upstream firms with high market status experience a steep drop in the number of KBAs, as their knowledge structure scope increases relative to upstream firms having 
low market status. On the other hand, downstream firms with high market status tend to benefit the most from a perceived alignment between their knowledge scope structure and value chain position when they have high knowledge scope levels. High market status amplifies the positive effect of alignment.

To further provide support to hypotheses $5(a, b)$ and $6(a, b)$, we tested whether the slopes for upstream and downstream positions with high and low levels of market status respectively were significantly different from each other (Aiken and West, 1991; Dawson and Richter, 2006). Table 3 shows the t-test statistics for the regression slope difference tests.

The slopes of the upstream firms for high and low market status interacting with knowledge depth were significantly different from each other $(t=-0.444, \mathrm{p}<.05)$, with upstream firms with high market status displaying a higher rate of alliance formation than those with lower market status. However, findings challenge hypothesis $5 \mathrm{~b}$, with high market status firms pursuing depthoriented strategies forming more KBAs than their low status counterparts. Their respective slopes were significantly different, as shown in Table $3(t=-3.114, \mathrm{p}<.001)$.

Insert Table 3 about here

As for knowledge scope, a partially different picture emerges. The slopes for high and low market status upstream firms were significantly different $(t=2.359, \mathrm{p}<.01)$, with upstream firms being sanctioned by high market status. As knowledge structure scope increases, the rate of alliance formation increases steeply for high market status downstream firms. On the other hand, low market status firms do not seem to get great benefits of increasing alignment as their knowledge structures move from low to high scope. Finally, the slopes for high and low market 
status downstream firms were significantly different $(t=-2.898, \mathrm{p}<.01)$. As knowledge structure scope increases, the rate of alliance formation increases steeply for high market status

downstream firms. On the other hand, low market status firms do not seem to get great benefits of increasing alignment as their knowledge structures move from low to high scope. ${ }^{4}$

\section{DISCUSSION}

\subsection{Summary and contribution}

Our study builds on and extends research on the drivers of KBAs by substantiating the extant understanding that the knowledge structure of a firm influences the decisions surrounding KBA formation (Zhang and Baden-Fuller, 2010; Zhang et al., 2007). We find that both specialization (i.e., knowledge depth) and attitude to exploration across multiple technological domains (i.e., knowledge scope) have a positive and significant impact on firms' tendency to ally. However, when we introduce a firm's market identity into the mix, a fuller and richer picture emerges. Our most important contribution is that we advance the understanding of the interplay between internal commitment to knowledge acquisition strategies and the externally induced set of

\footnotetext{
${ }^{4}$ To further test the robustness of all the interaction effects, we performed post-hoc, simple slope and regions of significance analyses at given positions along the value chain (Preacher et al., 2006). As for hypothesis 3 , the relationship between knowledge depth and tendency to form KBAs was statistically significant (i.e., at 1 SD below the mean, simple slope $.04, \mathrm{p}<.05$; at SD above the mean, simple slope $=-.51, \mathrm{p}<.05$ ). After computing regions of significance, we discovered that the negative association between knowledge depth and tendency to form KBAs becomes non-significant for value chain positions which score below -.69 $(p<.05)$, thus confirming the negative impact of a misaligned knowledge structure with respect to downstream value chain positions. In support of hypothesis 4, the relationship between knowledge scope and tendency to form KBAs was statistically significant, as well (i.e., at $1 \mathrm{SD}$ below the mean, simple slope $=-.30, \mathrm{p}<.05$; at $1 \mathrm{SD}$ above the mean, simple slope $=.10, \mathrm{p}<.05$ ). The relationship between knowledge scope and tendency to form KBAs turns non-significant for value chain positions which score below 0.68 , thus confirming the importance of a scope-oriented knowledge structure form firms occupying downstream positions along the value chain. We followed the same procedure for three-way interactions and found that, in support of hypothesis 5, the joint effect of knowledge structure and value chain position is positive and significant for upstream firms with high status (at $1 \mathrm{SD}$ above the mean value of degree centrality, simple slope of depth*value chain position $=.43, \mathrm{p}<.05$ ). The same effect turns negative but nonsignificant for firms with low market status. The region of significance indicates positive, significant $(p<.05)$ conditional effects for firms with a degree centrality above 2.88. Finally, the joint effect of knowledge scope and value chain position is positive and significant for high status firms (i.e., at $1 \mathrm{SD}$ above the mean value of degree centrality, simple slope of scope*value chain position $=.40, \mathrm{p}<.05$ ), thus providing further support to hypothesis 6 . As for hypothesis 5 , the region of significance indicates positive, significant $(\mathrm{p}<.05)$ conditional effects for firms with a degree centrality above 2.89 .
} 
expectations tied to the role each firm plays in its industry. We find that the existence of alignment (or misalignment) between a firm's knowledge structure characteristics and its value chain position not only increases (or decreases) the rate of KBA formation, but this relationship is further strengthened or weakened by the relative status in the market. As advocated by recent literature (Adner and Levinthal, 2002; Clegg et al., 2007; Stern et al., 2014), our study provides new theoretical insights on the importance of congruence between a firm's internal resource endowment and its external market position, especially in the context of firms in emerging industries. In the absence of well-established legitimacy indicators that firms in mature industries can be reliably differentiated upon, alignment between a firm's knowledge structure and its market identity becomes an important substitute to gauge the suitability of a firm as an alliance partner.

The misalignment effect in the context of KBA formation comes out more strongly when the knowledge characteristic in question is the scope of a firm's knowledge structure. Our findings suggest that when potential alliance partners evaluate upstream firms, they find the apparent misalignment between the specialized role of an upstream firm and a scope-oriented knowledge structure as a sign that the firm is either not interested in pursuing KBAs to complement their knowledge base or is likely engaging in suboptimal knowledge creation strategies.

An intriguing implication of our study is the role of market status in influencing KBA formation. The literature on organizational status and reputation provides ample evidence on the beneficial impact of market status on a firm's attractiveness and legitimacy as a valuable partner (Lin et al., 2009; Podolny, 1993; Stuart, 1998). The beneficial effects of market status dominate in the case of upstream firms. Our findings provide support for the argument that when firms occupy upstream value chain positions and have a strong depth orientation in their knowledge structures, they tend to form more KBAs when they have high social status. Not only are these firms 
perceived to be following optimal knowledge creation strategies, but their status provides additional signals about the quality of their technological and research expertise.

What are less well known however, are the potential hazards of having high social status in the context of KBA formation. Our findings suggest that there are situations where having high status can amplify the negative effects of misalignment between a firm's internal characteristics and its external market position, thereby presenting confusing signals about a firm's attractiveness as an alliance partner. In particular, high status upstream firms display a steep drop in their abilities to form KBAs when they leverage on a scope-oriented knowledge base. One possible explanation for this finding is that upstream firms are likely to be more prone to external audience evaluations in the context of emerging industries because they are supposed to be the main sources of the central technologies that drive the prospects for future growth. The sanctioning effect is reversed in the case of high-status downstream firms having a depth-oriented knowledge structure. In that case, external audiences seem to appreciate the balancing between closeness to the market and a deeply specialized knowledge base, when combined with a prominent structural position.

We also see our findings as contributing to the considerable interest in developing more marketoriented conceptions of organizational identity (Livengood and Reger, 2010; Uzuegbunam, 2016). We show the importance of differentiating between related but analytically distinct identity dimensions, as they may exert interdependent effects on organizational behavior. Value chain position and market status points towards the same direction when congruence exists between external expectations and internal knowledge configurations. More importantly, market status could make external sanctions more severe when associated with knowledge structures that transgress the expectations tied to a certain value chain category. 
Finally, heeding the call for further studies on knowledge-based strategies in highly dynamic, uncertain contexts, we advance our understanding of alliance behavior in emerging industries (Forbes and Kirsch, 2011). We show that knowledge base structure as a proxy of firms' ability to learn from allies may not be enough as a signal of quality to attract potential partners in an emerging industry. There are contexts in which relative dearth of information and unpredictable patterns due to high uncertainty may discourage firms to form KBAs due to the difficulty in reading knowledge configuration as a signal of technology quality. This finding is consistent with previous research on the failure of patents as signal of quality in the context of venture capital decision making (Hoenig and Henkel, 2015). We contribute to this research stream, by showing that when uncertainty prevails, market identity may serve as a heuristic of partners' ability to fulfill expectations.

An important empirical and managerial issue that emerges from this discussion is to understand how firms act when their organizational and market identities do not correspond or even contradict each other, thereby extending the resource alignment/misalignment argument that we explored in this study. Does a contradiction between a firm's organizational and market identity act as a generative or restrictive force, especially when one considers how other actors in the market choose to enter cooperative relationships with the focal firm? Strategic alliances by their very nature bring together firms that find some common grounds to cooperate, while at the same time continuing to pursue their idiosyncratic goals (Khanna et al., 1998). Managing the fine balance between the two goals is critical to ensure that the expectations of the partners are realized. Merely considering alliances as mechanisms for accessing and sharing resources offers a relatively narrow conception in terms of appreciating this tension between cooperation and conflict in alliances. It could very well be so that alliance partners can utilize market identities as ways to reassure partners and generate greater cooperation while still being able to appropriate 
private rents from each other's resource bases. In other words, firms may use partners' belonging to social categories to anticipate and get prepared to face the conflicts that might later occur.

\subsection{Limitations and future research}

Our paper opens potentially new grounds for appreciating the role social and market characteristics of a firm play in influencing the conditions under which its internal resources and capabilities affect strategic behaviour and outcomes. While our study takes an "ego-centric" approach towards market identity, i.e. we only consider the market identity of a focal firm, future research could consider a multi-dimensional view of market identity and look at the dispersion and/or concentration of market identities within the portfolio of a firm's strategic alliances and study how these properties influence subsequent patterns of alliance formation and outcomes (Mowery et al., 1998). For instance, it would be interesting to understand the differences in patterns of KBA formation, choice of governance modes, and performance when firms ally with partners sharing the same identity but having distant knowledge/technological profiles, and vice versa.

Further, our study offers insights to enrich the ongoing discussion on the challenges related to the simultaneous pursuit of contrasting inter- and intra-organizational learning strategies, that is, deep specialization into few technological domains versus exploration of multiple technological trajectories (Hagedoorn and Wang, 2012; Lavie et al., 2011). Advancing the idea that market identity may pose a set of expectations on firms' behavior and affect their attractiveness as alliance partners, our study proposes an alternative perspective on ways to overcome trade-offs in resource allocation and knowledge generation. We show that having the most appropriate knowledge configuration, given a certain value chain position, may act as an amplifying mechanism to attract potential allies. On the contrary, when misalignment happens, our findings point out either to the need for reassuring signals to counter the negative impact on alliance 
formation or the opportunity to change internal resource allocation in favor of that learning trajectory potential allies expect to observe. This situation is even more pronounced when misalignment is associated with higher levels of market status. External scrutiny is likely to occur, turning into steeper drops in attractiveness. Yet, we did not directly test the joint impact of depth and scope on KBA formation and in combination with market identity. Empirical evidence abounds on the beneficial impacts and limits of ambidexterity in affecting interorganizational agreements between firms (e.g., Lin et al., 2007). In this regard, market identity could represent an important boundary condition affecting the viability of pursuing simultaneous, conflicting learning trajectories.

Another limitation of our study relates to its focus on two specific dimensions of knowledge, that is, depth and scope of a knowledge base structure. Additional dimensions of a firm's knowledge structure could be considered, such as decomposability, malleability, or size (Yayavaram and Ahuja, 2008), as germane characteristics of a firm's knowledge structure. Coupled with these, future work can also consider the interplay of different knowledge structure characteristics with various types of governance modes and contractual relationships in developing a finer and richer understanding of why and how KBAs are formed and the conditions under which they generate the expected performance outcomes for participating firms.

Partly related to the previous point, we focused our analysis on KBA formation to predict the interplay of internal and external drivers. We were not able to disentangle the performance consequences of both congruence and inconsistency between knowledge configuration and external expectations. Future research could investigate how alignment or misalignment may improve or reduce innovation outcomes, as well as KBA performance through the different stages of an alliance life cycle. 
As a final remark, the focus on a single industry does limit the generalizability of our findings. More importantly, being in an emerging industry was not treated as a contingency factor, rather as an empirical setting. Nonetheless, we do believe that our findings are relevant for industries that are in relatively nascent stages of their development and where knowledge and technological trajectories are still in the pre-dominant design stage. Future research however, can benefit from considering alliances across a range of industries at different stages in the industry life cycle to discover important external boundary conditions. 


\section{REFERENCES}

Adner, R., Levinthal, D.A., 2002. The emergence of emerging technologies. California Management Review 45, 50-66.

Ahuja, G., 2000. Collaboration networks, structural holes, and innovation: A longitudinal study. Administrative Science Quarterly 45, 425-455.

Ahuja, G., Katila, R., 2001. Technological acquisitions and the innovation performance of acquiring firms: a longitudinal study. Strategic Management Journal 22, 197-220.

Aiken, L.S., West, S.G., 1991. Multiple regression : Testing and interpreting interactions. Sage Publications, Newbury Park, Calif.

Anand, B.N., Khanna, T., 2000. Do firms learn to create value? The case of alliances. Strategic Management Journal 21, 295-315.

Arora, A., Gambardella, A., 1990. Complementarity and external linkages: the strategies of the large firms in biotechnology. Journal of Industrial Economics 38, 361-379.

Avadikyan, A., Cohendet, P., Héraud, J.-A., 2012. The economic dynamics of fuel cell technologies. Springer Science \& Business Media.

Ballinger, G.A., 2004. Using generalized estimating equations for longitudinal data analysis. Organizational Research Method 7, 127-150.

Baron, J.N., 2004. Employing identities in organizational ecology. Industrial and Corporate Change 13, 3-32.

Benner, M.J., 2007. The incumbent discount: stock market categories and response to radical technological change. Academy of Management Review 32, 703-720.

Benner, M.J., Tushman, M.L., 2003. Exploitation, exploration, and process management: The productivity dilemma revisited. Academy of Management Review 28, 238-256.

Berchicci, L., 2013. Towards an open R\&D system: Internal R\&D investment, external knowledge acquisition and innovative performance. Research Policy 42, 117-127.

Blau, P.M., 1977. A macrosociological theory of social structure. American Journal of Sociology, 26-54.

Brown, J.E., Hendry, C.N., Harborne, P., 2007. An emerging market in fuel cells? Residential combined heat and power in four countries. Energy Policy 35, 2173-2186.

Chatterjee, S., Price, B., 1991. Regression analysis by example. Wiley, New York.

Chen, Y.-R., Peterson, R.S., Phillips, D.J., Podolny, J.M., Ridgeway, C.L., 2012. Introduction to the special issue: Bringing status to the table - attaining, maintaining, and experiencing status in organizations and markets. Organization Science 23, 299-307. 
Chung, S.A., Singh, H., Lee, K., 2000. Complementarity, status similarity and social capital as drivers of alliance formation. Strategic Management Journal 21, 1-22.

Clegg, S.R., Rhodes, C., Kornberger., M., 2007. Desperately seeking legitimacy: Organizational identity and emerging industries. Organization Studies 28, 495-513.

Colombo, M.G., Grilli, L., Piva, E., 2006. In search of complementary assets: The determinants of alliance formation of high-tech start-ups. Research Policy 35, 1166-1199.

Cook, R.D., Weisberg, S., 1983. Diagnostic for heteroskedasticity in regression. Biometrika 70, $1-10$.

Dawson, J.F., Richter, A.W., 2006. Probing three-way interactions in moderated multiple regression: Development and application of a slope difference test. Journal of Applied Psychology 91, 917-926.

Dickson, P.H., Weaver, K.M., 1997. Environmental determinants and individual-level moderators of alliance use. Academy of Management Journal 40, 404-425.

Forbes, D.P., Kirsch, D.A., 2011. The study of emerging industries: Recognizing and responding to some central problems. Journal of Business Venturing 26, 589-602.

Franco, M., Haase, H., 2015. Interfirm alliances: a taxonomy for SMEs. Long Range Planning $48,168-181$.

Gambardella, A., McGahan, A.M., 2010. Business-model innovation: General purpose technologies and their implications for industry structure. Long Range Planning 43, 262-271.

Glynn, M.A., Navis, C., 2013. Categories, identities, and cultural classification: Moving beyond a model of categorical constraint. Journal of Management Studies 50, 1124-1137.

Graffin, S.D., Bundy, J., Porac, J.F., Wade, J.B., Quinn, D.P., 2013. Falls from Grace and the Hazards of High Status The 2009 British MP Expense Scandal and Its Impact on Parliamentary Elites. Administrative Science Quarterly 58, 313-345.

Grant, R.M., Baden-Fuller, C., 2004. A knowledge accessing theory of strategic alliances. Journal of Management Studies 41, 61-84.

Gulati, R., 1999. Network location and learning: the influence of network resources and firm capabilities on alliance formation. Strategic Management Journal 20, 397-420.

Hagedoorn, J., Cloodt, M., 2003. Measuring innovative performance: is there an advantage in using multiple indicators? Research Policy 32, 383-400.

Hagedoorn, J., Wang, N., 2012. Is there complementarity or substitutability between internal and external R\&D strategies? Research Policy 41, 1072-1083.

Hausman, J., Hall, B.H., Griliches, Z., 1984. Econometric models for count data with an application to the patents-R\&D relationship. Econometrica 52, 909-938. 
Hausman, J.A., 1978. Specification tests in econometrics. Econometrica 46, 1251-1271.

Hess, A.M., Rothaermel, F.T., 2011. When are assets complementary? Star scientists, strategic alliances, and innovation in the pharmaceutical industry. Strategic Management Journal 32, 895909.

Hillman, A.J., Shropshire, C., Cannella Jr, A.A., 2007. Organizational predictors of women on corporate boards. Academy of Management Journal 50, 941-952.

Hoang, H., Rothaermel, F.T., 2010. Leveraging internal and external experience: Exploration, exploitation and R\&D project performance. Strategic Management Journal 31, 734-758.

Hoenig, D., Henkel, J., 2015. Quality signals? The role of patents, alliances, and team experience in venture capital financing. Research Policy 44, 1049-1064.

Hsu, G., Hannan, M.T., 2005. Identities, Genres, and Organizational Forms. Organization Science 16, 474-490.

Isaksson, O.H., Simeth, M., Seifert, R.W., 2016. Knowledge spillovers in the supply chain: Evidence from the high tech sectors. Research Policy 45, 699-706.

Jaccard, J., Turrisi, R., 2003. Interaction effects in multiple regression, 2nd ed. Sage Publications, Thousand Oaks, Calif.; London.

Jensen, M., 2003. The role of network resources in market entry: Commercial banks' entry into investment banking, 1991-1997. Administrative Science Quarterly 48, 466-497.

Jensen, M., 2010. Legitimizing illegitimacy: How creating market identity legitimizes illegitimate products. Research in the Sociology of Organizations 31, 39-80.

Jensen, M., Kim, B.K., Kim, H., 2011a. The importance of status in markets: A market identity perspective. Status in management and organizations 48, 87-117.

Jensen, M., Kim, H., Kim, B.K., 2011b. The importance of reputation in markets: Towards an integration of role and reputation theory, in: Barnett, M.L., Pollock, T.G. (Eds.), The Oxford Handbook of Corporate Reputation. Oxford University Press, Oxford, UK, pp. 87-117.

Jensen, P.H., Palangkaraya, A., Webster, E., 2015. Trust and the market for technology. Research Policy 44, 340-356.

Katila, R., Ahuja, G., 2002. Something old, something new: A longitudinal study of search behavior and new product introduction. Academy of Management Journal 45, 1183-1194.

Kavusan, K., Noorderhaven, N.G., Duysters, G.M., 2016. Knowledge acquisition and complementary specialization in alliances: The impact of technological overlap and alliance experience. Research Policy 45, 2153-2165.

Kelly, D., Amburgey, T.L., 1991. Organizational inertia and momentum: A dynamic model of strategic change. Academy of Management Journal 34, 591-612. 
Khanna, T., Gulati, R., Nohria, N., 1998. The dynamics of learning alliances: competition, cooperation, and relative scope. Strategic Management Journal 19, 193-210.

Kim, B.K., Jensen, M., 2011. How product order affects market identity: Repertoire ordering in the US opera market. Administrative Science Quarterly 56, 238-256.

Kogut, B., Zander, U., 1996. What firms do? Coordination, identity, and learning. Organization Science 7, 502-518.

Lavie, D., Kang, J., Rosenkopf, L., 2011. Balance within and across domains: The performance implications of exploration and exploitation in alliances. Organization Science 22, 1517-1538.

Lavie, D., Rosenkopf, L., 2006. Balancing exploration and exploitation in alliance formation. Academy of Management Journal 49, 797-818.

Leiponen, A., 2005. Core complementarities of the corporation: Organization of an innovating firm. Managerial and Decision Economics 26, 351-365.

Liang, K.-Y., Zeger, S.L., 1986. Longitudinal data analysis using generalized linear models. Biometrika 73, 13-22.

Lin, Z., Yang, H., Arya, B., 2009. Alliance partners and firm performance: resource complementarity and status association. Strategic Management Journal 30, 921-940.

Lin, Z.J., Yang, H., Demirkan, I., 2007. The performance consequences of ambidexterity in strategic alliance formations: Empirical investigation and computational theorizing. Management Science 53, 1645-1658.

Livengood, R.S., Reger, R.K., 2010. That's our turf! Identity domains and competitive dynamics. Academy of Management Review 35, 48-66.

March, J.G., 1991. Exploration and exploitation in organizational learning. Organization Science 2, 71-87.

Mata, J., Woerter, M., 2013. Risky innovation: The impact of internal and external R\&D strategies upon the distribution of returns. Research Policy 42, 495-501.

Meier, M., 2011. Knowledge management in strategic alliances: a review of empirical evidence. International Journal of Management Reviews 13, 1-23.

Mowery, D.C., Oxley, J.E., Silverman, B.S., 1998. Technological overlap and interfirm cooperation: implications for the resource-based view of the firm. Research Policy 27, 507-523.

Navis, C., Glynn, M.A., 2010. How new market categories emerge: Temporal dynamics of legitimacy, identity, and entrepreneurship in satellite radio, 1990-2005. Administrative Science Quarterly 55, 439-471. 
Nygaard, S., 2008. Co-evolution of technology, markets and institutions. The case of fuel cells and hydrogen technology in Europe. Centre for Innovation, Research and Competence in the Learning Economy (CIRCLE), Lund University, Lund, Sweden.

Pilkington, A., 2004. Technology portfolio alignment as an indicator of commercialisation: an investigation of fuel cell patenting. Technovation 24, 761-771.

Podolny, J.M., 1993. A status-based model of market competition. American Journal of Sociology 98, 829-872.

Podolny, J.M., 2001. Networks as the Pipes and Prisms of the Market. American Journal of Sociology 107, 33-60.

Podolny, J.M., 2010. Status signals: A sociological study of market competition. Princeton University Press.

Porac, J.F., Thomas, H., Baden-Fuller, C., 1989. Competitive groups as cognitive communities: the case of scottish knitwear manufacturers. Journal of Management Studies 26, 397-416.

Powell, W.W., Koput, K.W., Smith-Doerr, L., 1996. Interorganizational Collaboration and the Locus of Innovation: Networks of Learning in Biotechnology. Administrative Science Quarterly 41, 116-145.

Preacher, K.J., Curran, P.J., Bauer, D.J., 2006. Computational tools for probing interactions in multiple linear regression, multilevel modeling, and latent curve analysis. Journal of educational and behavioral statistics 31, 4 437-448.

Quintana-García, C., Benavides-Velasco, C.A., 2008. Innovative competence, exploration and exploitation: The influence of technological diversification. Research Policy 37, 492-507.

Rosenkopf, L., Almeida, P., 2003. Overcoming local search through alliances and mobility. Management Science 49, 751-766.

Rosenkopf, L., Nerkar, A., 2001. Beyond local search: boundary-spanning, exploration, and impact in the optical disk industry. Strategic Management Journal 22, 287-306.

Rothaermel, F.T., Deeds, D.L., 2004. Exploration and exploitation alliances in biotechnology: A system of new product development. Strategic Management Journal 25, 201-221.

Schilling, M.A., Green, E., 2011. Recombinant search and breakthrough idea generation: An analysis of high impact papers in the social sciences. Research Policy 40, 1321-1331.

Schmiedeberg, C., 2008. Complementarities of innovation activities: An empirical analysis of the German manufacturing sector. Research Policy 37, 1492-1503.

Schoots, K., Kramer, G.J., Van Der Zwaan, B.C.C., 2010. Technology learning for fuel cells: An assessment of past and potential cost reductions. Energy Policy 38, 2887-2897. 
Shipilov, A., Gulati, R., Kilduff, M., Li, S., Tsai, W., 2014. Relational pluralism within and between organizations. Academy of Management Journal 57, 449-459.

Silverman, B.S., Baum, J.A., 2002. Alliance-based competitive dynamics. Academy of Management Journal 45, 791-806.

Stern, I., Dukerich, J.M., Zajac, E., 2014. Unmixed signals: How reputation and status affect alliance formation. Strategic Management Journal 35, 512-531.

Stuart, T.E., 1998. Network positions and propensities to collaborate: an investigation of strategic alliance formation in a high-technology industry. Administrative Science Quarterly 43, 668-698.

Stuart, T.E., Ozdemir, S.Z., Ding, W.W., 2007. Vertical alliance networks: The case of university-biotechnology-pharmaceutical alliance chains. Research Policy 36, 477-498.

Subramanian, A.M., Bo, W., Kah-Hin, C., 2018. The role of knowledge base homogeneity in learning from strategic alliances. Research Policy 47, 158-168.

Tripsas, M., 2009. Technology, identity, and inertia through the lens of "The Digital Photography Company". Organization Science 20, 441-460.

Tripsas, M., Gavetti, G., 2000. Capabilities, cognition, and inertia: Evidence from digital imaging. Strategic Management Journal 21, 1147-1161.

Uzuegbunam, I., 2016. Identity and initial structure in inter-firm alliances: A social identity perspective. Management Decision 54, 929-945.

Vasudeva, G., Anand, J., 2011. Unpacking absorptive capacity: A study of knowledge utilization from alliance portfolios. Academy of Management Journal 54, 611-623.

Wang, Q., von Tunzelmann, N., 2000. Complexity and the functions of the firm: breadth and depth. Research Policy 29, 805-818.

Wang, Y., Rajagopalan, N., 2015. Alliance Capabilities: Review and Research Agenda. Journal of Management 41, 236-260.

Wei, M., Smith, S.J., Sohn, M.D., 2017. Experience curve development and cost reduction disaggregation for fuel cell markets in Japan and the US. Applied Energy 191, 346-357.

White, H., 1980. A heteroskedasticity-consistent covariance matrix estimator and a direct test for heteroskedasticity. Econometrica 48, 817-838.

Wooldridge, J.M., 2001. Econometric Analysis of Cross Section and Panel Data, 5th ed. MIT Press, Cambridge, MA.

Yang, H., Steensma, H.K., 2014. When do firms rely on their knowledge spillover recipients for guidance in exploring unfamiliar knowledge? Research Policy 43, 1496-1507. 
Yayavaram, S., Ahuja, G., 2008. Decomposability in Knowledge Structures and Its Impact on the Usefulness of Inventions and Knowledge-base Malleability. Administrative Science Quarterly $53,333-362$.

York, J.G., Lenox, M.J., 2014. Exploring the sociocultural determinants of de novo versus de alio entry in emerging industries. Strategic Management Journal 35, 1930-1951.

Zhang, J., Baden-Fuller, C., 2010. The Influence of Technological Knowledge Base and Organizational Structure on Technology Collaboration. Journal of Management Studies 47, 679704.

Zhang, J., Baden-Fuller, C., Mangematin, V., 2007. Technological knowledge base, R\&D organization structure and alliance formation: Evidence from the biopharmaceutical industry. Research Policy 36, 515-528.

Zhou, K.Z., Li, C.B., 2012. How knowledge affects radical innovation: Knowledge base, market knowledge acquisition, and internal knowledge sharing. Strategic Management Journal 33, 10901102.

Zuckerman, E.W., 1999. The Categorical Imperative: Securities Analysts and the Illegitimacy Discount. American Journal of Sociology 104, 1398-1397. 
FIGURE 1

Visual Description of the Hypothesized Relationships Predicting Knowledge-Based

Alliances

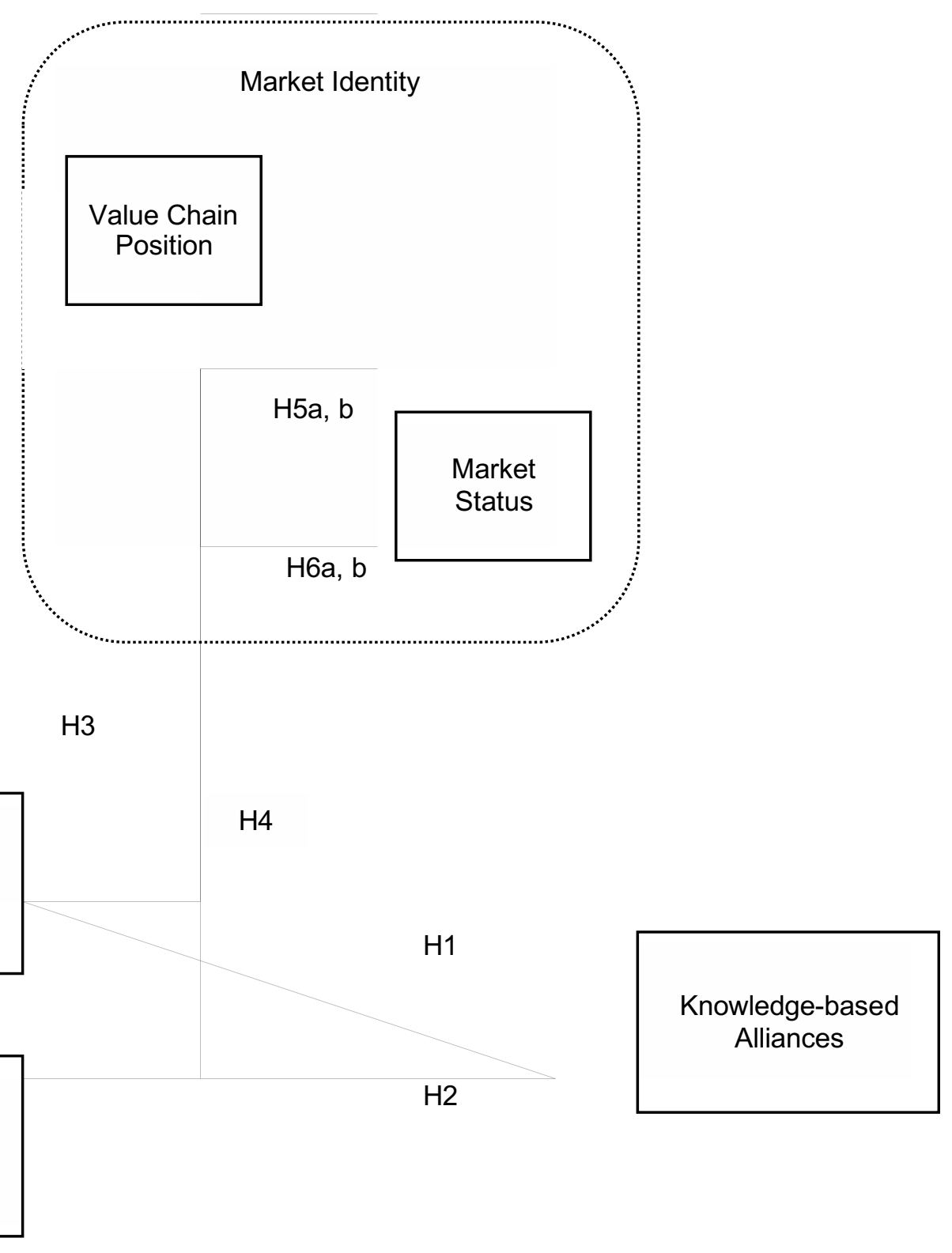




\section{TABLE 1}

\section{Means, Standard Deviations, and Correlations}

\begin{tabular}{|c|c|c|c|c|c|c|c|c|c|c|}
\hline & Mean & SD & 2 & 3 & 4 & 5 & 6 & 7 & 8 & 9 \\
\hline 1 Intangible assets & 5.22 & 1.54 & & & & & & & & \\
\hline 2 Financial solvency ratio & 40.25 & $25.70-0.26^{* *}$ & & & & & & & & \\
\hline 3 Firm size & 3.41 & $1.430 .84^{* *}$ & $-0.21^{* *}$ & & & & & & & \\
\hline 4 Public company & 0.37 & $0.480 .51^{* *}$ & -0.00 & $0.66^{* *}$ & & & & & & \\
\hline 5 Specialization & 0.30 & $0.38-0.05^{\star}$ & 0.04 & $-0.05^{\star}$ & $-0.02^{*}$ & & & & & \\
\hline 6 Firm age & 53.26 & $44.230 .53^{* *}$ & $-0.17^{* *}$ & $0.60^{* *}$ & $0.38^{* *}$ & $-0.06^{* *}$ & & & & \\
\hline 7 Acquisition experience & 2.10 & $5.630 .06^{*}$ & 0.00 & $0.08^{* *}$ & $0.17^{* *}$ & $-0.03^{* *}$ & $0.08^{* *}$ & & & \\
\hline 8 Alliance experience & 0.54 & 1.390 .04 & $0.05^{*}$ & 0.03 & $0.10^{* *}$ & $0.06^{* *}$ & -0.00 & $0.04^{* *}$ & & \\
\hline 9 Knowledge depth & 0.84 & $1.780 .12^{* *}$ & 0.02 & $0.15^{\star *}$ & $0.11^{* *}$ & $0.19^{* *}$ & $0.05^{*}$ & -0.01 & $0.16^{* *}$ & \\
\hline 10 Knowledge scope & 1.54 & $0.990 .13^{* *}$ & $-0.08^{* *}$ & $0.21^{* *}$ & $0.08^{* *}$ & $0.27^{* *}$ & $0.05^{*}$ & 0.00 & $0.04^{*}$ & $0.07^{* *}$ \\
\hline 11 Value chain position & 0.12 & $1.050 .28^{* *}$ & $-0.18^{* *}$ & $0.21^{* *}$ & $0.15^{\star *}$ & 0.00 & $0.12^{* *}$ & -0.02 & $0.07^{* *}$ & $0.09^{* *}$ \\
\hline 12 Market status & 0.53 & $0.84-0.11^{*}$ & $0.31^{* *}$ & $-0.15^{\star *}$ & $0.15^{\star *}$ & 0.02 & -0.06 & -0.00 & $0.43^{* *}$ & $0.19^{* *}$ \\
\hline 13 R\&D alliances & 0.22 & $0.58-0.01$ & 0.04 & 0.01 & $0.08^{* *}$ & $0.08^{*}$ & -0.02 & $0.05^{* *}$ & $0.16^{* *}$ & $0.20^{* *}$ \\
\hline
\end{tabular}


TABLE 2

Results of Regression Analyses Predicting Tendency to Form R\&D Alliances

\begin{tabular}{lccc}
\hline Variables & Model & Model & Model \\
& 1 & $\mathbf{2}$ & $\mathbf{3}$ \\
\hline Constant & $.65^{*}$ & 1.41 & $.65^{*}$ \\
Intangible assets & $-.04 \dagger$ & $-.74^{* *}$ & -.07 \\
Financial solvency ratio & $-.03^{* *}$ & $-.01^{*}$ & $-.02^{* * *}$ \\
Firm size & $.12^{*}$ & $.41^{*}$ & .04 \\
Public company & .03 & $1.59^{* *}$ & .12 \\
Specialization & $.01^{* * *}$ & $.10 \dagger$ & $.51^{*}$ \\
Firm age & $-.01^{* * *}$ & -.00 & $-.00^{* *}$ \\
Acquisition experience & $.01^{* * *}$ & $.01^{* * *}$ & $.01^{*}$ \\
Alliance experience & $1.01^{* * *}$ & $1.08^{* * *}$ & $.17^{* *}$ \\
Plastics materials and synthetics & $-1.02^{* * *}$ & $-2.06^{* * *}$ & $-.33^{*}$ \\
Electrical industrial apparatus & .33 & .18 & .07 \\
R\&D and testing services & $-.71^{* *}$ & -.12 & $.98^{*}$ \\
Dummy year and country & $I n c l u d e d$ & $I n c l u d e d$ & $I n c l u d e d$ \\
Knowledge depth & & $.31^{* * *}$ & $.23^{* * *}$ \\
Knowledge scope & & $.26^{* *}$ & $.10^{* *}$ \\
\hline Value chain position & & $.10^{*}$ \\
Knowledge depth $x$ Value chain position & & $-.46^{* * *}$ \\
Knowledge scope $x$ Value chain position & & $.14^{* *}$
\end{tabular}




\section{FIGURE 2}

Effects of Interaction between Knowledge structure, Value Chain Position, and Market Status on the Tendency to form KBAs
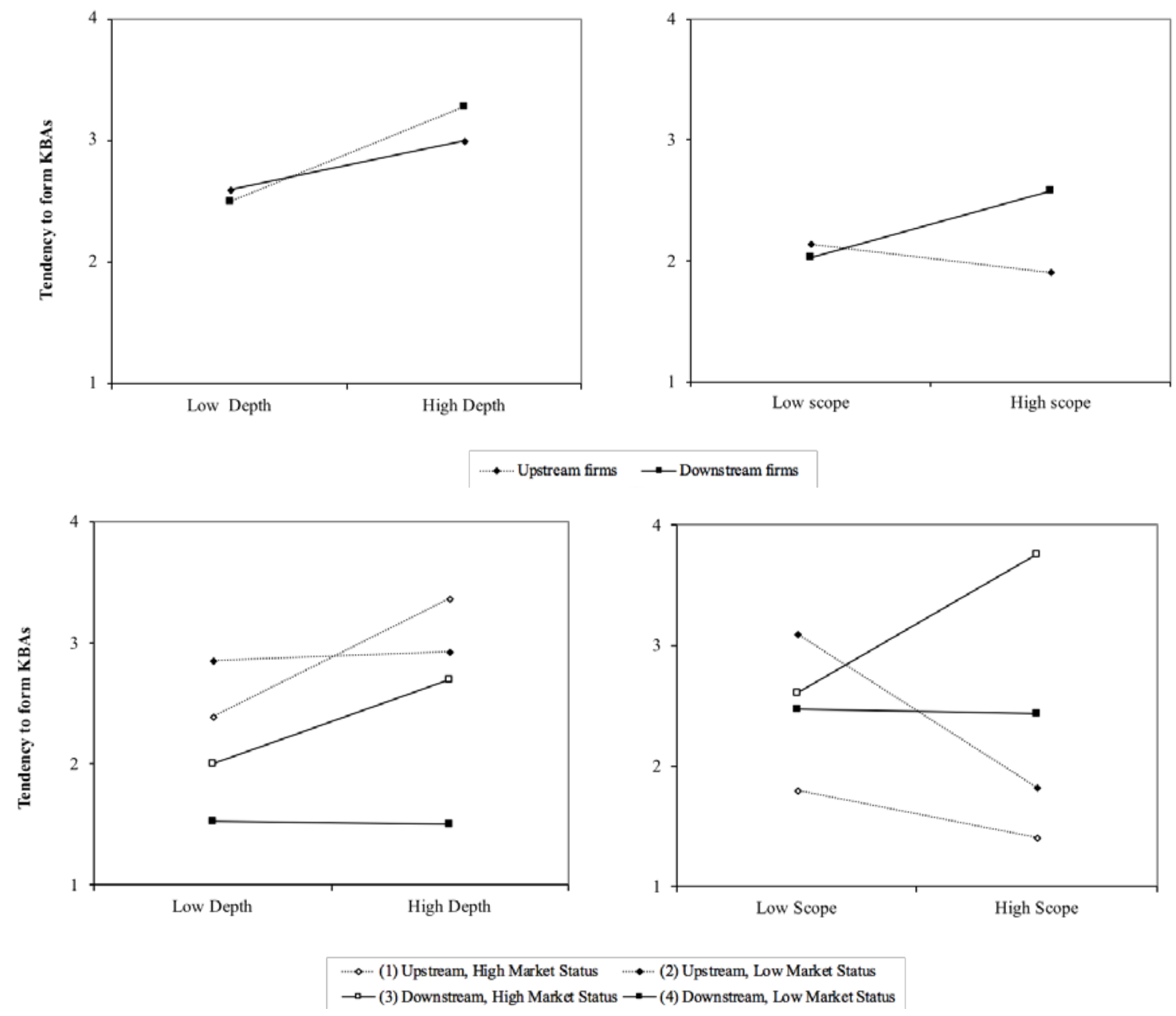
TABLE 3

t-Tests for Simple Slopes of 3-Way Regression Effects of Knowledge Structure Characteristics, Value Chain Position, and Market Status on KBAs

\begin{tabular}{|c|c|c|c|}
\hline \multicolumn{2}{|c|}{} & $\begin{array}{c}\text { Knowledge } \\
\text { Structure Depth }\end{array}$ & $\begin{array}{c}\text { Snowledge } \\
\text { Structure Scope }\end{array}$ \\
\hline Slope (1) & Slope (2) & t-statistic & t-statistic \\
\hline Upstream Firm, & Upstream Firm, & $.444^{*}$ & $2.359^{* *}$ \\
\hline $\begin{array}{l}\text { High Market Status } \\
\text { High Market Status }\end{array}$ & Low Market Status & $-2.114^{* * *}$ & $-298^{* *}$ \\
\hline$* * * \mathrm{p}<.001 ; * * p<.01 ; * p<.05 ; p<.10$ & Downstream Firm, & \\
\hline
\end{tabular}

